\title{
TANGGUNG JAWAB PELAKU USAHA DENGAN SISTEM DROPSHIP DITINJAU DARI PERSPEKTIF UU NOMOR 8 TAHUN 1999 TENTANG PERLINDUNGAN KONSUMEN
}

\author{
Irwan Maulana \\ STAI Asy-Syukriyyah Tangerang \\ irwan.maulana@asy-syukriyyah.ac.id \\ Fachrul Marasabessy \\ STAI Asy-Syukriyyah Tangerang \\ fachrulmarasabessy@ymail.com \\ Prio Ambardi \\ STAI Asy-Syukriyyah Tangerang \\ prio.ambardi@asy-syukriyyah.ac.id
}

\begin{abstract}
Abstrak:Teknologi informasi telah berkembang pesat, dan mempengaruhi beberapa aspek dalam kehidupan manusia termasuk dalam transaksi jual beli. Transaksi online memungkinkan penjual dan pembeli tidak bertemu secara langsung. Perkembangannya muncul suatu sistem jual beli baru yang dinamakan dropship. Dalam UU perdagangan pun, jual beli online menjadi perhatian. Tentang jual beli online sudah di jelaskan dalam UU No. 7 Tahun 2014 Tentang Perdagangan (UU Perdagangan) dan UU No. 8 tahun 1999 tentang Perlindungan Konsumen (UU Perlindungan Konsumen) menjadi acuan bagi setiap pelaku usaha dalam melakukan transaksi perdagangan, baik perdagangan konvensional maupun perdagangan melalui online atau e-commerce. Tujuan dari penelitian ini adalah untuk menggambarkan bagaimana pandangan atau penafsiran UU No.8 Tahun 1999 berkaitan dengan tanggung jawab pelaku usaha yang menggunakan sistem drop shipper. Adapun metode penelitian ini merupakan library reaseach. Adapun hasil dari penelitian ini adalah hukum positif hukum jual beli dropship adalah boleh dan keabsahan serta ketentuan perjanjiannya dapat disandarkan Undang-undang Nomor 11 Tahun 2008 tentang Informasi dan Transaksi Elektronik dan Undang-Undang Nomor 8 Tahun 1999 tentang Perlindungan Konsumen dimana startup khususnya tokopedia tetap bertanggung jawab sesuai dengan ketentuan undang-undang no 8 tahun 2011
\end{abstract}

Kata Kunci: Wakaf, Hak Cipta, Fatwa Islam

\section{Pendahuluan}

Manusia adalah makhluk sosial, dalam memenuhi kebutuhan hidupnya tidak dipungkiri dalam kesehariannya selalu ketergantungan satu sama lain dan selalu hidup bersama antar kelompok. Dalam memenuhi kebutuhan hidupnya manusia tidak mungkin terlepas dari 
kegiatan perdagangan barang maupun jasa. Perdagangan terjadi melalui tatap muka atau secara langsung yaitu antara merchant (penjual) dan buyer (pembeli) pada tempat tertentu seperti toko, pasar, tempat pameran, maupun pada waktu tertentu sesuai dengan jam operasional toko atau tempat yang bersangkutan. ${ }^{1}$

Dalam islam kita juga tidak hanya diajarkan mengenai hubungan manusia dengan Tuhannya yang hanya berupa ibadah, tetapi juga mengatur hubungan manusia dengan manusia lainnya yang disebut muamalah. Manusia bermuamalah hampir $80 \%$ dalam waktu 24 jam. Islam juga adalah agama yang sesuai dengan fitrah manusia memberikan beban dan kewajiban kepada umatnya sesuai dengan kadar dan kemampuannya. ${ }^{2}$

Perkembangan jual beli dalam era yang modern ini telah banyak membawa perubahan, seperti diantaranya memanfaatkan media internet, sehingga proses jual beli semakin mudah dan cepat. Dengan cara menjual, mempromosikan dan persaingan harga hanya tanpa terbatas jarak, waktu kapanpun dan dimana pun dan dengan siapapun.

Jual beli atau perdagangan menggunakan media internet yang disebut electronic commerce (e-commerce) kini sudah tidak asing lagi dalam dunia bisnis di negara-negara berkembang maupun maju termasuk di Indonesia. ${ }^{3}$ E- commerce menjadi lebih berkembang dalam hal model transaksi jual beli, yaitu diantaranya adalah model transaksi jual beli dropshipping atau model dari bagian jenis bisnis online afiliasi, yaitu pelaku bisnis dropship memasarkan produk orang lain melalui fasilitas online lewat internet. baik berupa barang maupun jasa, produk-produk tersebut bukan merupakan produk sendiri.

Jual beli dalam sistem Dropshipping menjadi buah bibir para pembisnis online dan kini menjadi model bisnis yang diminati pembisnis online baru dengan modal kecil bahkan tanpa ada modal. Karena dropship (toko online) tidak pernah menyetok dan menyediakan tempat penyetokan barang melainkan hanya mempromosikan melalui toko online dengan memasang foto dan kriteria barang dan harga. Model dropship ini barang biasanya didapat dari jalinan kerja sama dengan perusahaan lain atau toko lain berupa toko online atau toko fisik yang memiliki barang yang sesungguhnya, yang disebut dropshipper. ${ }^{4}$

UU No. 7 Tahun 2014 Tentang Perdagangan (UU Perdagangan) dan UU No. 8 tahun 1999 tentang Perlindungan Konsumen (UU Perlindungan Konsumen) menjadi acuan bagi

\footnotetext{
${ }^{1}$ Yuli Kurniaty, Heni Hendrawati. 2015. Jual beli online dalam prespektif Hukum Islam. jurnal transformasi, $11(1): 65$

${ }^{2}$ Imam Mustofa. 2013. Ijtihad Kontemporer Menuju Fiqih Kontekstual. Jakarta: Rajawali Pers. h. 143.

${ }^{3}$ Gemala Dewi. 2005. Hukum Perikatan Islam di Indonesia . Jakarta : Prenada Media. h. 201

${ }^{4}$ Feri Sulianta. 2014. Terobosan Berjualan Online Ala Dropshipping . Yogyakarta: Penerbit Andi. h. 2.
} 
setiap pelaku usaha dalam melakukan transaksi perdagangan, baik perdagangan konvensional maupun perdagangan melalui online atau e-commerce. Dalam UU Perdagangan, diatur mengenai sistem perdagangan elektronik dengan ketentuan bahwa setiap orang atau badan usaha yang memperdagangkan barang atau jasa wajib menyediakan data dan informasi secara lengkap dan benar. E-commerce ini diatur dalam UU Perdagangan Bab VIII mengenai Perdagangan Melalui Sistem Elektronik pada pasal 65 dan 66. Sementara untuk ketentuan lebih lanjut akan diatur dalam Peraturan Pemerintah yang hingga saat ini masih didorong penyelesaiannya. UU Perlindungan konsumen merupakan pedoman pelaku usaha dan konsumen dapat menjalankan usahanya secara fair dan tidak merugikan konsumen. Perlindungan konsmen dalam era digital e-commerce ini menjadi hal yang penting dan dibutuhkan, ketika penjual dan pembeli hanya bermodalkan asas kepercayaan dalam melakukan transaksi perdagangan elektronik. Jangan sampai perdagangan elektronik dijadikan alat bagi orang- orang yang tidak bertanggung jawab dalam memasarkan produknya.

Berdasarkan uraian diatas, penulis ingin mengkaji transaksi jual beli sistem dropshipping dalam perspektif fiqih muamalah dan menurut UU No. 8 Tahun 1999 Tentang perlindungan Konsumen.

\section{Kajian Teori}

\section{Tanggung Jawab Pelaku Usaha}

Definisi Pelaku usaha menurut Pasal 1 angka (3) Undang-Undang Nomor 8 Tahun 1999 tentang Perlindungan Konsumen. ${ }^{5}$ Pelaku usaha adalah setiap orang atau perseorangan atau badan usaha, baik yang berbentuk badan hukum maupun bukan badan hukum yang didirikan dan berkedudukan atau melakukan perjanjian kegiatan usaha dalam berbagai bidang ekonomi di wilayah hukum negara Republik Indonesia.

Di Negara Indonesia semua pelaku usah mempunyai hak yang sama dan diatur dalam Undang-Undang Pasal 6 Nomor 8 Tahun 1999 tentang Perlindungan Konsumen, telah mengatur mengenai hak-hak bagi pelaku usaha yakni:

a) Hak untuk menerima pembayaran

b) Hak untuk mendapat perlindungan hukum

c) Hak untuk melakukan pembelaan diri

\footnotetext{
${ }^{5}$ N.H.T. Siahaan. 2005. Hukum Konsumen,Perlindungan danTanggungJawab Produk. Bogor: Grafika Mardi Yuana. hlm. 23
} 
d) Hak untuk rehabilitasi nama baik apabila terbukti secara hukum bahwa kerugian konsumen tidak diakibatkan oleh barang dan/atau jasayang diperdagangkan; ${ }^{6}$

e) Hak-hak yang diatur dalam ketentuan peraturan perundang- undangan lainnya.

Sebelum Mendapatkan Hak pelaku usaha wajib melaksanakan kewajiban mereka sebagai pelaku usaha antara lain: yang diatur dalam Pasal 7 Undang-Undang Nomor 8 Tahun 1999 tentang Perlindungan Konsumen:

a) Beritikad baik dalam melakukan kegiatan usahanya;

b) Memberikan informasi yang benar, jelas, dan jujur mengenai kondisi dan jaminan barang dan/atau jasa serta memberi penjelasan penggunaan, perbaikan, dan pemeliharaan;

c) Memperlakukan atau melayani konsumen secara benar dan jujur serta tidak diskriminatif;

d) Menjamin mutu barang dan/atau jasa yang diproduksi dan/atau diperdagangkan berdasarkan ketentuan standar mutu barang dan/atau jasa yang berlaku;

e) Memberi kesempatan kepada konsumen untuk menguji dan/atau mencoba barang dan/atau jasa tertentu serta memberi jaminan dan/atau garansi atas barang yang dibuat dan/atau diperdagangkan;

f) Memberi kompensasi, ganti rugi, dan/atau penggantian apabila barang dan/atau jasa yang diterima atau dimanfaatkan konsumen tidak sesuai dengan perjanjan.

Dalam UUPK tampak bahwa itikad baik lebih ditekankan pada pelaku usaha, karena meliputi semua tahapan dalam melakukan kegiatan usahanya, sehingga dapat diartikan bahwa kewajiban pelaku usaha untuk beritikad baik dimulai sejak barang dirancang / diproduksi sampai pada tahap penjualan, sebaliknya konsumen hanya diwajibkan beritikad baik dalam melakukan transaksi pembelian barang dan/atau jasa.

Pelaku usaha juga memiliki tanggung jawab yang harus dipikul sehingga konsumen akan mengalami kebahgiaan yang hakiki. ${ }^{7}$ Tanggung jawab dalam bahasa Inggris diterjemahkan dari kata "responsibility" atau "liability", sedangkan dalam bahasa Belanda, yaitu "vereentwoodelijk" atau "aansparrkelijkeid". Tanggung jawab adalah wajib menanggung, wajib memikul beban, wajib memenuhi segala akibat yang timbul dari perbuatan, rela mengabdi, dan rela berkorban untuk kepentingan pihak lain. ${ }^{8}$

\footnotetext{
${ }^{6}$ UU No. 8 Tahun 1999 tentang Hukum Perlindungan Konsumen

${ }^{7}$ Fauzan Fauzan, (2012) "Etika Bisnis Islam dalam Pandangan Filsafat Ilmu (Telaah Atas Pemikiran Etika Immanuel Kant)," Jurnal Ekonomi Modernisasi 8(2): 92.

${ }^{8}$ Khaerul Tanjung, "Pelaku Usaha dan Tanggung Jawab", http://www.blogster.com/ khaerulhtanjung/pelakuusaha dan-tanggung-jawab. Diakses pada tanggal 16 Juni 2019. pukul 09.27 WIB.
} 
Tanggung jawab produk adalah suatu tanggung jawab secara hukum dari orang atau badan hukum yang menghasilkan suatu produk (produser manufactur) atau dari orang atau badan yang bergerak dalam suatu proses untuk menghasilkan suatu produk (processor assembler) atau dari orang atau badan yang menjual atau yang mendistribusikan (seller, distributor) produk tersebut dan perbuatan yang tidak melanggar hak-hak dan kepentingan konsumen, menimbulkan kerugian, atau kesehatan konsumen terganggu. ${ }^{9}$

Tanggung Jawab harus dipikul bagi seorang pelaku usaha diantaranya adalah: Tanggung Jawab Berdasarkan Kelalaian, Tanggung Jawab Wan Prestasi, dan Tanggung Jawab Mutlak. Pelaku Usaha jangan hanya mencari keuntungan semata akan tetapi harus me manage resiko serta mampu mengatsi segala hal termasuk memikul ketiga tanggung jawab tersebut yang berkaitan langsung dengan konsumen.

\section{Dropshipping}

Dropshipping adalah suatu teknik pemasaran di mana penjual tidak menyimpan stok barang dan jika penjual mendapat order penjual tersebut langsung meneruskan order dan detail pengiriman barangnya ke distributor, supplier, atau produsen, lalu kemudian distributor, supplier, atau produsen akan mengirimkan barang langsung ke pembeli dengan nama pengirim langsung si penjual. ${ }^{10}$

Para pihak yang terkait dalam kegiatan jual beli dropshipping di atas saling berkaitan satu sama lain dari awal proses penawaran sampai dengan penerimaan barang diiklankan. Kegiatan jual beli ini dilakukan dengan tahapan penawaran barang oleh dropshipper sampai diterimanya barang oleh konsumen.

Berdasarkan skema tersebut adanya hubungan hukum yang timbul antara dropshipper dengan supplier adalah perjanjian kerjasama. Hubungan hukum antara dropshipper dengan konsumen adalah perjanjian jual beli yang mana dropshipper sebagai perantara jual beli, dan hubungan hukum antara supplier dengan konsumen adalah perjanjian jual beli di mana supplier sebagai penjual utama.

Tentunya skema dropshipper ini sangat menarik apalagi di era digital sekarang yang semuanya pingin serba cepat dan instan sehingga mempunyai keunggulan tersendiri antara lain keunggulan dari dropshipper ini yakni:

\footnotetext{
${ }^{9}$ Lukmanul Hakim, (2012). "Tanggung Jawab Produsen Dalam Perdagangan Bebas,” Among Makarti 3(2): 50.

${ }^{10}$ Reny Elisa Lumban Gaol. 2018. Perlindungan Hukum Terhadap Para Pihak dalam Transaksi Jual Beli Pakaian Jual Beli Pakaian Melalui Media Internet. Jurnal Universitas Sumatera Utara. 5(1): 14
} 
a) Tidak memerlukan modal atau investasi yang besar. Cukup hanya bermodal media sosial dan pulsa untuk mempromosikan dan menjalin komunikasi dengan calon buyer.

b) Tidak membutuhkan ruangan penyimpanan persediaan barang.

c) Tidak adanya stok barang dalam penjualan, hanya mempromosikan, lalu ketika ada buyer dropshipper akan menghubungi supplier, lalu supplier akan mengirimkan produk tersebut ke alamat buyer dengan data pengirim nama kita / dropshipper. Semua proses adalah tanggungjawab supplier.

d) Tidak harus mempunyai tingkat pendidikan yang tinggi. Siapapun bisa mengikuti atau menggeluti bisnis usaha dropshipping ini karna tidak memerlukan syarat pendidikan yang tinggi.

e) Fleksibel (dapat melakukan transaksi penjualan di mana saja). Alur transaksi yang berbasis online sehingga memudahkan bagi dropshipper untuk melakukan kegiatan usaha ini di manapun, kapanpun secara fleksibel.

f) Sangat mudah dijalankan oleh semua orang

g) Tidak terkait waktu dalam pengolahannya. ${ }^{11}$

Dari kelebihan diatas menunjukkan bahwasannya menurut asumsi penulis menjadi seorang dropshipper justru memudahkan kita bagi yang ingin membuka usah sdengan modal yang minim sehingga mampu mengangkat perekonomian masing-masing individu. Akan tetapi tentu didalam kelebihan pasti suatu konsep memiliki keleman yang menjadi acuan untuk menjadi lebih baik antar lain kelemahan menurut hemat penulis dari dropshipper yakni:

a) Tidak dapat mengontrol persediaan barang

b) Kurangnya kepastian pengiriman barang yang dikirim ke pembeli sesuai atau tidak.

c) Biaya pengiriman mahal

d) Terbatasnya keuntungan.

\section{UU No. 8 Tahun 1999 Tentang Perlindungan Konsumen}

Perlindungan konsumen merupakan hal yang sangat penting dalam hukum Islam. Karena Islam melihat, bahwa perlindungan konsumen bukan sebagai hubungan keperdataan saja, melainkan menyangkut kepentingan publik secara luas, bahkan menyangkut hubungan

\footnotetext{
${ }^{11}$ Ahmad Syafii. 2013. Step by Step Bisnis Dropshipping dan Reseller. Jakarta: PT. Elex Media Komputindo. h. 25
} 
antara manusia dan Allah SWT. Maka perlindungan terhadap konsumen muslim berdasarkan syariat Islam merupakan kewajiban negara.

Pengertian hak adalah kepentingan hukum yang dilindungi oleh hukum, sedangkan kepentingan adalah tuntutan yang diharapkan untuk dipenuhi. Rumusan-rumusan norma yang terdapat di dalam masih bersifat relatif abstrak, oleh karena itulah untuk menjamin agar rumusan hak dan kewajiban tersebut dapat direalisasikan, maka kita harus menghubungkan hak dan kewajiban yang telah terusmus dengan berbagai norma-norma yang menjadi pendukungnya.

Adapun Hak Konsumen Menurut UU No.8 Tahun 1999 yang termaktub di dalam pasal 4 yakni:

a. Hak atas kenyamanan, keamanan, dan keselamatan dalam mengkonsumsi barang dan/atau jasa;

b. Hak untuk memilih barang dan/atau jasa serta mendapatkan barang dan/atau jasa tersebut sesuai dengan nilai tukar dan kondisi serta jaminan yang dijanjikan;

c. Hak atas informasi yang benar, jelas, dan jujur mengenai kondisi dan jaminan barng dan/atau jasa;

d. Hak untuk didengar pendapat dan keluhannya atas barang dan/atau jasa yang digunakan;

e. Hak untuk mendapatkan advokasi, perlindungan, dan upaya penyelesaian sengketa perlindungan konsumen secara patut;

f. Hak untuk mendapat pembinaan dan pendidikan konsumen;

g. Hak untuk diperlakukan atau dilayani secara benar dan jujur serta tidak diskriminatif;

h. Hak untuk mendapatkan kompensasi, ganti rugi dan/atau penggantian, apabila barang dan/atau jasa yang diterima tidak sesuai dengan perjanjian atau tidak sebagaimana mestinya;

i. Hak-hak yang diatur dalam ketentuan peraturan perundang-undangan lainnya. ${ }^{12}$

Perlindungan terhadap konsumen sgat diagungkan oleh pemerintah yang dipayungi oleh UU tersebut. Karena jika tidak ada hak bagi konsumen nantinya para pelaku usaha bertindak sewenang-wanang terhadap konsemen. Tentunya seorang konsumen sebelum mendapatkan hak tersebut maka seorang konsumen harus melampaui kwajiban-kewajibannya yang termaktub dalam UU No. 8 Tahun 1999 Pasal 5 yakni:

\footnotetext{
${ }^{12}$ Pasal 4 UU No. 8 Tahun 1999 tentang Perlindungan Konsumen.
} 
1) Membaca atau mengikuti petunjuk informasi dan prosedur pemakaian atau pemanfaatan barang dan/atau jasa, demi keamanan dan keselamatan;

2) Beritikad baik dalam melakukan transaksi pembelian barang dan/atau jasa;

3) Membayar sesuai dengan nilai tukar yang disepakati;

4) Mengikuti upaya penyelesaian hukum sengketa perlindungan konsumen secara patut. ${ }^{13}$

Tentunya dalam kegiatan jual beli melibatkan semua subjek yakni konsumen dan pelaku usaha dimana mereka saling berhubungan satu sama lain baik via udara maupun langsung face to facei kegiatan ini terkadang bisa menjadi efek yang negatif atau dalam tanda kutip merugikan baik kepada konsumen maupun pelaku usah tujuan dari diadakan UU perlindungan konsumen ini adalah untuk memunculkan simbiosis mutualisme satu sama lain baik bagi pelaku usaha maupum konsumen. Dalam hal ini selain terdapatnya aturan maka juga terdapat sanksi bagi yang terlibat didalamnya.

Apabila iklan berpotensi menimbulkan kerugian kepada konsumen, maka harus dipertimbangkan kemungkinan terdapatnya peluang untuk meminta pertanggungjawaban para pihak yang terlibat dalam kegiatan periklanan, terutama pelanggaran-pelanggaran terhadap ketentuan yang terdapat dalam UUPK.

Dalam UUPK, kemungkinan untuk meminta pertanggungjawaban para pihak pada kegiatan periklanan telah disesuaikan dengan dua kemungkinan tersebut. Misalnya, bagi pengiklan dimungkinkan berdasarkan ketentuan dalam Pasal 19 UUPK sebagai berikut: ${ }^{14}$

1) Pelaku usaha bertanggung jawab memberikan ganti rugi atas kerusakan, pencemaran, dan atau kerugian konsumen akibat mengkonsumsi barang dan atau jasa yang dihasilkan atau diperdagangkan.

2) Ganti rugi sebagaimana dimaksud pada ayat (1) dapat berupa pengembalian uang atau penggantian barang dan/atau jasa yang sejenis atau setara nilainya, atau perawatan kesehatan dan/atau pemberian santunan yang sesuai dengan ketentuan peraturan perundangundangan yang berlaku.

3) Pemberian gantirugi dilaksanakan dalam tenggang waktu 7 (tujuh) hari setelah tanggal transaksi.

\footnotetext{
${ }^{13}$ Pasal 5 UU No. 8 Tahun 1999 tentang Perlindungan Konsumen.

${ }^{14}$ Pasal 19 UU No. 8 Tahun 1999 tentang Perlindungan Konsumen.
} 
4) Pemberian ganti rugi sebagaimana dimaksud pada ayat (1) dan ayat (2) tidak menghapuskan kemungkinan adanya tuntutan pidana berdasarkan pembuktian lebih lanjut mengenai adanya unsur kesalahan.

5) Ketentuan sebagaimana dimaksud pada ayat (1) dan ayat (2) tidak berlaku apabila pelaku usaha dapat membuktikan bahwa kesalahan tersebut merupakan kesalahan konsumen.

Pemberian Sanksi dalam pelanggaran sebenarnya bukan untuk bertujuan menganiaya atau memihak kepada salah satu pihak justru pemberian sanksi ini sebagai jembatan penengah atau sebagai moderator dalam kegiatan jual beli dari sisi online maupun offline.

\section{Metode Penelitian}

Pendekatan dalam penelitan ini adalah pendekatan kualitatif yang bersifat deskriptifinterpretatif. Jenis penelitian yang digunakan adalah library research. Data yang diperoleh adalah narasi deskriptif mengenai rancangan Undang-undang, terutama mengkaji peraturan tentang hukum perlindungan konsumen terhadap jual beli online dan hukum Islam.

Sebagai penelitian library research, teknik pengumpulan data yang digunakan adalah dokumentasi, dengan mengambil data yang berasal dari berbagai literatur yang relevan.

\section{Pembahasan}

\section{Tanggung Jawab Pelaku Usaha (Dropshipper)}

Di Indonesia sendiri semakin banyak juga toko-toko online yang beredar di sosial media atau jual beli melalaui media internet,. Di Indonesia sendiri terciptalah bebrapa market place yang fungsinya menaungi para penjual dan pembeli. Seperti diantaranya yaitu Tokpedia adalah salah satu Market Place yang cukup diminati oleh penggunanya yang terdiri dari penjual dan pembeli. Dan pelayanan Tokopedia yang dapat digunakan secara gratis oleh semua orang.

Tokopedia memudahkan seluruh masyarakat Indonesia dari Sabang sampai Merauke untuk mendapatkan kebutuhan mereka. Selain berperan sebagai marketplace pertama yang menerapkan sistem escrow atau rekening bersama di Indonesia, Tokopedia juga menjadi perusahaan teknologi pertama di Indonesia yang memperkenalkan pengentaran instan melalui kemitraan dengan perusahaan transportasi daring. Hal ini memungkinkan konsumen untuk mendapatkan barang dengan cepat.

Namun disini, penulis akan membahas tentang jual beli dropship atau jual beli tanpa mempunyai stok barang bagi dropshipper. Dropshipper hanya mempromosikan barang yang 
dijual dengan deskripsi barang secara spesifik. Kita akan membahas penjual / dropshipper yang ada di tokopedia, namun bukan terdaftar sebagai penjual, penjual / dropshipper tersebut hanya terdaftar sebagai pembeli namun sistem menjual barangnya bukan lewat market place Tokopedia, namun mempromosikan barangnya melewati sosial media lainya. Namun pengambilan barang yang dijual diambil / dipesan dari Tokopedia.

Lalu, bagaimana mengenai tanggung jawab dropshipper kepada pemmbeli didalam market place Tokopedia? Nah, seperti yang sudah dibahas di bab sebelumnya, tentang tanggung jawab tokopedia dari bebrapa syarat dan ketentuan yang diberlakukan di tokopedia.

Beberapa tanggung jawab yang kemungkinan terjadi dan bagaimana solusi dari market Place Tokopedia tersebut antara lain,

1) Tokopedia memiliki hak untuk membantu menyelesaikan kendala anatara penjual dan pembeli.

2) Tokopedia berwenang untuk mengambil keputusan atas permasalahan tersebut dengan melihat bukti-bukti yang ada dan/atau bukti-bukti baru yang harus dilengkapi masingmasing pihak.

3) Tokopedia berwenang untuk melakukan mediasi dan/atau mengambil keputusan untuk penyelesaian masalah didalam diskusi Pusat Resolusi, meskipun salah satu pihak (Pembeli atau Penjual) belum memberikan tanggapan atas solusi yang diberikan Pusat Resolusi dalam jangka waktu 1 x 24 jam, dalam hal: (i) Adanya informasi dari pihak ketiga yang berkaitan dalam jalannya transaksi, yakni antara lain kurir pengiriman yang memberikan informasi terkait status terkini dari resi pengiriman paket; (ii) Bukti dari Pembeli dan/atau Penjual yang dikirimkan melalui jalur komunikasi lain (email Tokopedia, Layanan Pengguna, dan lainnya) yang perlu diteruskan ke Pusat Resolusi dengan dasar transparansi masalah; (iii) Laporan dari salah satu pihak disebabkan adanya kelalaian Pembeli atau Penjual; (iv) Salah satu pihak (Pembeli atau Penjual) terindikasi melakukan tindakan kecurangan; atau (v) Kondisi tertentu yang menyebabkan Tokopedia perlu segera melakukan mediasi.

4) Atas keputusan pertama Tokopedia diatas, baik Pembeli dan Penjual memiliki hak untuk banding, dengan persyaratan bahwa pihak yang mengajukan upaya banding harus mengajukan bukti baru di luar dari bukti-bukti sebelumnya.

5) Pembeli dan Penjual dengan ini menyetujui bahwa Keputusan Tokopedia atas upaya banding adalah keputusan akhir yang tidak dapat diganggu gugat dan mengikat pihak Penjual dan Pembeli untuk mematuhinya. 
6) Pengguna memahami bahwa Pusat Resolusi tidak berlaku untuk produk pakaian dalam bekas, kendala yang berkaitan dengan rasa, aroma dan/atau tekstur produk, dan semua produk dalam daftar jenis barang yang dilarang diperjual-belikan di Tokopedia seperti yang ada di halaman Syarat dan Ketentuan.

7) Pembeli dan Penjual memahami dan menyetujui bahwa dalam penyelesaian kendala di Pusat Resolusi, Pembeli dan Penjual wajib memberikan tanggapan atas kendala yang ada hingga selesai dengan mematuhi ketentuan dan batas waktu sebagaimana yang telah ditentukan pihak Tokopedia pada diskusi terkait.

Dropshipper disini adalah penjual yang mendaftar akun sebagai pembeli ditokopedia. Adapun masalah yang terjadi dengan costumernya. mengenai tanggung jawab sebagai dropshipper bisa diajuakan ke pihak supplier melalui pengajuan bantuan namun dengan syarat yang disepakati dalam took supplier tersebut. Bisa dengan pengembalian barang atau uang apabila terjadi kesalahan dari supplier seperti: barang rijek, tidak sampai, dan barang tidak sesuai pesanan. Ini berlaku dengan kesepakatan kedua pihak namun pihak tokopedia yang menjadi jembatan untuk mencari solusinya.

\section{Praktek Jual Beli Dropship Ditinjau Dari Perpsektif UU No. 8 Tahun 1999 Tentang Hukum Perlindungan Konsumen}

Lahirnya akad jual beli apabila adanya kesepakatan dalam suatu perjanjian antara dua pihak atau lebih untuk melakukan dan atau tidak melakukan perbuatan hukum tertentu. Dalam hal ini akad jual beli dropship dapat terjadi apabila adanya kesepakatan dalam suatu perjanjian antara pihak pertama yaitu suplier dengan pihak kedua yaitu dropshiper. Hingga saat ini, belum ada peraturan yang mengatur secara langsung mengenai jual beli dropship. Namun, keabsahan transaksi ini bisa dilihat dari beberapa ketentuan perjanjian yang terdapat dalam KUHPerdata/BW dan Undang-Undang Nomor 8 Tahun 1999 tentang Perlindungan Konsumen. Jual beli dropship tidak terlepas dari konsep jual beli secara mendasar yang tercantum dalam Pasal 1457 KUH Perdata yang menjelaskan bahwa jual beli adalah suatu perjanjian, dengan mana pihak yang satu. mengikatkan dirinya untuk menyerahkan suatu kebendaan, dan pihak yang lain untuk membayar harga yang telah dijanjikan. ${ }^{15}$

\footnotetext{
${ }^{15}$ Bima Prabowo, Ery Agus Priyono dan Dewi Hendrawati Tanggung Jawab ., h. 3.
} 
Jual beli dropship tidak jauh berbeda dengan proses jual beli konvensional. Jual beli konvensional pembeli dan penjual bertemu dan bertatapan muka secara langsung dan pada jual beli secara dropship penjual dan pembeli tidak bertemu secara langsung melainkan dilakukan secara online.

Adanya kesamaan antara jual beli konvensional dengan jual beli dropship ini membuat konsep perjanjian dalam KUHPerdata dapat juga diterapkan dalam jualbeli dropship. Meskipun demikian, perlu juga merujuk ketentuan transaksi elektronik sebagai mana yang diatur dalam Undang - Undang Nomor 11 Tahun 2008 Tentang Informasi dan Transaksi Elektronik (ITE).

Ketentuan yang ada dalam undang-undang ini dapat digunakan sebagai penunjuk keabsahan jual beli online. Pasal 1 ayat (2) Undang - Undang ITE menyebutkan bahwa Transaksi Elektronik adalah perbuatan hukum yang dilakukan dengan menggunakan Komputer, jaringan Komputer, dan/atau media elektronik lainnya. ${ }^{16}$

Seperti layaknya perjanjian pada umumnya, perjanjian jual beli dropship dapat tercapai jika syarat - syarat sahnya suatu perjanjian sudah terpenuhi. Syarat sahnya suatu perjanjian tersebut adalah yang tercantum dalam Pasal 1320 KUH Perdata, yaitu: sepakat mereka yang mengikatkan diri, kecakapan untuk membuat suatu perjanjian, Suatu hal tertentu dan sebab yang halal.

Apabila keempat syarat sahnya perjanjian yang diatur dalam Pasal 1320 KUH Perdata dipenuhi dalam perjanjian jual beli dropship maka telah terjadi perjanjian diantara mereka yang menimbulkan hubungan hukum yang berakibat timbulnya hak dan kewajiban bagi masingmasing pihak.

Keberadaan suatu kontrak atau perjanjian jual beli termasuk juga jual beli dropship juga tidak terlepas dari asas-asas yang mengikatnya, untuk mencapai kata sepakat dalam perjanjian, para pihak harus sama-sama memiliki ieetikad baikdan memberikan kebebasan untuk menentukan hal-hal apa sajakah yang harus dicantumkan dalam perjanjian tanpa adanya paksaan, sebab perjanjian ini akan berlaku sebagai suatu undang-undang bagi para pihak yang sepakat membuatnya.

Asas Pacta Sunt Servanda adalah salah satu asas yang ada dalam perjanjian. Asas Pacta Sunt Servanda (asas janji itu mengikat) adalah bahwa dalam suatu perjanjian yang paling penting adalah isinya yakni keterikatan para pihak. Pasal 1313 Kitab Undang-undang Hukum

\footnotetext{
${ }^{16}$ Undang - Undang Nomor 11 Tahun 2008 Tentang Informasi dan Transaksi Elektronik Pasal 1 ayat (2).
} 
Perdata (KUH Perdata) menyatakan bahwa perjanjian adalah: suatu perbuatan dengan mana 1(satu) orang atau lebih mengikatkan dirinya terhadap 1 (satu) orang lain atau lebih. ${ }^{17}$

Setelah terjadi pemesanan dalam jual beli dropship, selanjutnya maka pembeli akan diminta mentransfer sejumlah uang senilai harga barang dan biaya pengiriman barang kepada dropshipper dan dropshipper akan mentransfernya ke penjual. Jika telah mentransfer sejumlah uang tersebut, maka penjual akan mengirim barang ke alamat pembeli dengan menggunakan nama dropshipper sebagai pengirim.

Sebagaimana telah peneliti sebutkan sebelumnya, bahwa dalam perjanjian jual beli dropship menimbulkan hubungan hukum para pihak diantaranya adalah dropshiper dengan konsumen. Akibat dari hubungan hukum dropshiper dengan konsumen tersebut timbullah adanya hak dan kewajiban antar pihak yang bersangkutan.

Kewajiban pihak penjual dan pihak pembeli diatur dalam pasal 1473 - 1518 KUH Perdata, yaitu:

a. Kewajiban Penjual

Kewajiban penjual dalam pasal 1474 KUH Perdata) yaitu: menyerahkan hak milik atas barang yang diperjual belikan dan menanggung kenikmatan tentram atas barang tersebut dan menanggung terhadap cacat- cacat yang tersembunyi.

b. Kewajiban Pembeli

Kewajiban utama pembeli adalah membayar harga pembelian pada waktu dan tempat sebagaimana ditetapkan menurut perjanjian sebagaimana diatur dalam Pasal 1513 KUH Perdata. Jika pada waktu pembuatan persetujuan tidak ditetapkan maka si pembeli harus membayar ditempat dan pada waktu dimana penyerahan dilakukan (Pasal 1514 KUH Perdata). Undang - Undang Nomor 8 Tahun 1999 tentang Perlindungan Konsumen yang selanjutnya disebut sebagai UUPK menjamin perlindungan bagi pihak konsumen yang biasanya berada di posisi tawar yang rendah. hak - hak konsumen diatur dalam pasal 4 UUPK.

Pasal 4 huruf c UUPK menjelaskan bahwa konsumen juga berhak untuk memdapatkan informasi yang benar, jelas dan jujur mengenai barang yang akan diperjual belikan terlebih dalam transaksi jual beli dengan system dropship konsumen tidak melihat barang yang dijual secara langsung sehingga informasi tersebut sangat berarti bagi pembeli.

\footnotetext{
${ }^{17}$ R. Subekti dan R. Tjitrosudibio, Kitab Undang-Undang Hukum Perdata, (Jakarta: Pradnya Paramita, 2009), Pasal 1313
} 
Pasal 4 huruf h UUPK menjelaskan bahwa konsumen mempunyai hak untuk mendapatkan kompensasi, ganti rugi dan/atau penggantian, apabila barang dan/atau jasa yang diterima tidak sesuai dengan perjanjian atau tidak sebagaimana mestinya. ${ }^{18}$

Pasal 19 ayat (1) Undang - Undang Nomor 8 Tahun 1999 Tentang Perlindungan konsumen mengatakan bahwa "Pelaku usaha bertanggung jawab memberikan ganti kerugian konsumen akibat mengonsumsi barang dan/atau jasa yang dihasilkan atau diperdagangkan". ${ }^{19}$

Melihat substansi Pasal 19 ayat (1) tersebut dapat diketahui bahwa tanggung jawab dropshiper sebagai pelaku usaha meliputi: tanggung jawab ganti kerugian atas kerusakan, pencemaran, dan kerugian konsumen. Tanggung jawab pelaku usaha meliputi segala kerugian yang dialami konsumen sebagaimana yang di atur dalam Pasal 7 huruf f UUPK menyebutkan bahwa pelaku usaha berkewajiban untuk memberi kompensasi, ganti rugi, dan/atau penggantian apabila barang dan/atau jasa yang diterima atau dimanfaatkan konsumen tidak sesuai dengan perjanjian. $^{20}$

\section{Kesimpulan}

Jual beli dropship di Market Place Tokopedia merupakan jual beli yang bisa dikatakan aman, tanggung jawab untuk pelaku usaha atau dropshipper ketika terjadi kerugian / kesalahan dapat diadukan ke pihak suppier dan kemudian pihak tokopedia ynag memberikan solusi untuk menyelesaikan masalah diantara para pihak. Sementara itu, menurut hukum positif hukum jual beli dropship adalah boleh dan keabsahan serta ketentuan perjanjiannya dapat disandarkan Undang-undang Nomor 11 Tahun 2008 tentang Informasi dan Transaksi Elektronik dan Undang-Undang Nomor 8 Tahun 1999 tentang Perlindungan Konsumen. Mengenai dropship di tokopedia pun terbilang jelas dengan syarat-syarat yang ditetapkan oleh pihak tokopedia tersebut. Tokopedia terbilang amanah dalam proses tanggung jawabnya, tokopedia dengan syarat-syarat yang ditetapkannya pun terbilang bisa meminimalisir kerugian yang dialami oleh penjual maupun pembeli.

\footnotetext{
18 Undang-undang Nomor 8 Tahun 1999 Pasal 4 Huruf b dan c.

${ }^{19}$ Undang-undang Nomor 8 Tahun 1999 Pasal 19 Ayat (1).

${ }^{20}$ Undang-undang Nomor 8 Tahun 1999 Pasal 7 Huruf f.
} 


\section{Daftar Pustaka}

Dewi. 2005. Hukum Perikatan Islam di Indonesia . Jakarta : Prenada Media

Fauzan, Fauzan. 2012. Etika Bisnis Islam dalam Pandangan Filsafat Ilmu (Telaah Atas Pemikiran Etika Immanuel Kant).Jurnal Ekonomi Modernisasi 8 (2): 90-117.

Gaol. 2018. Perlindungan Hukum Terhadap Para Pihak dalam Transaksi Jual Beli Pakaian Jual Beli Pakaian Melalui Media Internet. Jurnal Universitas Sumatera Utara. 5(1): 14 Hakim, Lukmanul. 2012. Tanggung Jawab Produsen Dalam Perdagangan Bebas.” Among Makarti 3(2)

Kurniaty, Heni Hendrawati. 2015. Jual beli online dalam prespektif Hukum Islam. jurnal transformasi, 11(1)

Mustofa. 2013. Ijtihad Kontemporer Menuju Fiqih Kontekstual. Jakarta: Rajawali Pers.

Sulianta. 2014. Terobosan Berjualan Online Ala Dropshipping . Yogyakarta: Penerbit Andi.

Siahaan. 2005. Hukum Konsumen,Perlindungan danTanggungJawab Produk. Bogor: Grafika Mardi Yuana.

Undang-Undang No.8 Tahun 1999 tentang Perlindungan Konsumen 